\title{
Efektivitas Penggunaan Buku Saku Higiene Menstruasi dan Pencegahan Kekerasan dalam Situasi Bencana Pada Remaja Putri
}

\author{
Lita Angelina Saputri ${ }^{1 *}$, Iin Prima Fitriah ${ }^{2}$, Yussie Ater Merry ${ }^{3}$ \\ 1,2,3 Jurusan Kebidanan, Polteknik Kesehatan Kementerian Kesehatan Padang \\ *Email : litaangelinas@yahoo.com
}

\begin{abstract}
Background: Menstruation hygiene and violence in disaster situation can cause serious problems for adolescent girls. Poor menstrual hygiene during disaster can increase the risk of reproductive tract infections and violence can lead to unwanted pregnancy, abortion and psychological trauma. Approximately $80 \%$ of the needs of adolescent girls are not met during disaster. They need to be prepared to be able to empower themselves in dealing with disaster situations. Pocket book is one of the media to increase knowledge. The purpose of this study was to determine the effect of the use of menstrual hygiene pocket books and prevention of violence in disaster situations on the knowledge of adolescent girls. Methods: This research method is pre experiment with one group pre test and post test design. The study was conducted in May to October 2019 at SMAN 7 Lubuk Buaya Padang with 51 respondents using proportionate random sampling. Research instrument using questionnaire. Univariate and bivariate data analysis used Chi Square with 95\% confidence level. Results: There is a significant effect of the use of pocket book on the knowledge of adolescent girls about menstrual hygiene and prevention of violence in disaster situations $(p=0,000)$. Conclusion: It is hoped that the school can utilize the pocket book to increase the knowledge and preparedness of adolescent girls in dealing with disaster situations.
\end{abstract}

Keywords: adolescent girls, menstrual hygiene, violance prevention

\section{PENDAHULUAN}

Indonesia secara geografis terletak pada pertemuan tiga lempeng tektonik dunia, yaitu lempeng Australasia, lempeng Pasifik serta lempeng Eurasia, dan Filipina. Hal ini menyebabkan Indonesia rentan secara geologis. Selain itu, kurang lebih 5.590 daerah aliran sungai (DAS) yang terdapat di Indonesia, yang terletak antara Sabang dan Merauke, mengakibatkan Indonesia menjadi salah satu negara yang berisiko tinggi terhadap ancaman bencana gempa bumi, tsunami, deretan erupsi gunung api (129 gunung api aktif), dan gerakan tanah (BNPB, 2017). Badan Nasional Penanggulangan Bencana (BNPB) mencatat sepanjang tahun 2018 terjadi 1134 bencana alam di Indonesia yang terdiri dari 374 bencana banjir, 433 puting beliung, 38 kebakaran hutan, 268 tanah longsor, serta gempa dan tsunami.
Sumatera Barat merupakan salah satu provinsi di Indonesia yang rawan kejadian bencana. Badan Penanggulangan Bencana Daerah (BPBD) provinsi Sumatera Barat mencatat sepanjang tahun 2017 terjadi sebanyak 725 kejadian bencana alam yang terdiri dari abrasi, banjir, banjir bandang, erupsi gunung api, gelompang pasang, gempa bumi, kebakaran, kekeringan, longsor dan puting beliung. Kota Padang merupakan kota di provinsi Sumatera Barat dengan kejadian bencana tertinggi sepanjang tahun 2017, yaitu 155 kejadian (BNPB, 2017).

Bencana (disaster) dapat menyebabkan korban jiwa, luka, kehilangan tempat tinggal dan harta benda, pengungsian, kemiskinan, kehilangan mata pencaharian dan kehilangan tempat tinggal. Kegawatdaruratan bencana akan memberikan efek paling buruk bagi 
perempuan dan anak-anak (Bhattacharjee, 2019). Bencana tidak hanya memberikan efek buruk bagi kesehatan secara umum, namun juga mempengaruhi kesehatan reproduksi (Maknun, Nahar \& Kabir, 2017). Women Comission for Refugees menyatakan beberapa masalah kesehatan reproduksi yang mungkin muncul dalam kondisi darurat adalah meningkatnya risiko kekerasan seksual, meningkatnya risiko penularan infeksi menular seksual dan HIV, meningkatnya risiko kehamilan tidak diinginkan, kekurangan gizi serta kematian (Kemenkes RI, 2017).

Remaja putri merupakan salah satu kelompok yang paling terdampak dalam situasi bencana. Meskipun sangat penting ternyata kesehatan reproduksi masih sering terabaikan pada situasi krisis kesehatan termasuk bagi remaja (Sommer, M., Schmitt, M. \& Clatworthy, 2017). Masalah mestruasi adalah salah satu masalah yang sering dihadapi remaja putri pada situasi bencana. Walaupun proses menstruasi adalah hal yang fisiologis, namun pada situasi bencana kondisi ini dapat menimbulkan masalah (SPLASH, 2015).

Pada situasi darurat, sering terjadi keterbatasan akses terhadap kebutuhan selama menstruasi termasuk kamar mandi yang bersih dan tertutup bagi perempuan termasuk remaja putri (Krishnan \& Twigg, 2016). Hasil penelitian Suryati (2013), mendapatkan bahwa pada kondisi gempa tahun 2009 terlihat bahwa kesehatan reproduksi khususnya remaja putri kurang diperhatikan. Ini dibuktikan dengan tidak tersedianya kit bagi remaja putri yang mengalami menstruasi, padahal sebesar $95,10 \%$ remaja putri terdampak gempa membutuhkan duk atau pembalut.

Selain masalah higiene selama mestruasi, masalah lain yang sering dihadapi remaja putri pada situasi bencana adalah risiko menjadi korban kekerasan seksual, kekerasan fisik, psikologis dan eksploitasi dan kemiskinan serta berisiko menjadi korban perdagangan orang (human traficking) (Masson et al., 2016). Hal ini terjadi karena banyak remaja yang terpisah dari keluarga atau masyarakat, program pendidikan formal dan informal terhenti dan jaringan masyarakat dan sosial terganggu (UNFPA, 2016).

Dalam situasi bencana, dimana keadaan sangat tidak stabil, tingkat stres tinggi, keadaan serba terbatas, sarana MCK yang semi terbuka, ketiadaan kamar ganti, tempat pengungsian yang relatif terbuka membuat remaja putri sangat rentan menjadi korban kekerasan. Perempuan dapat mengalami berbagai macam kekerasan mulai dari kekerasan fisik (pemukulan, penganiayaan), psikologis (ancaman, pembatasan kegiatan), seksual (pelecehan seksual, perkosaan), maupun ekonomi (menjadi korban trafiking - perdagangan perempuan dan anak, dilacurkan dan lain-lain) (UNFPA, 2016). Bahkan dalam banyak kasus kekerasan yang ditemukan, lokasi kejadiannya bisa di tempat umum misalnya tempat-tempat pengungsian atau dalam rumah tangga (kekerasan dalam rumah tangga). Pelakunya pun bisa siapa saja, suami, ayah, pacar, relawan kemanusiaan, sesama pengungsi, maupun aparat pemerintah (Kemenkes RI, 2017).

Masalah higiene menstruasi dan kekerasan terhadap remaja putri pada situasi bencana memberikan dampak yang cukup serius. Kondisi dalam pengungsian belum cukup optimal untuk memenuhi kebutuhan reproduksi dan tidak cukup untuk melindungi perempuan dari kejadian kekerasan. Sistem pembuangan sampah medis seperti pembalut wanita 
yang belum baik menyebabkan rawan terjadi penularan infeksi. Selain itu kamar mandi yang belum terpisah antara lakilaki dan perempuan menyebabkan rawannya pelecehan seksual.

Dalam upaya memenuhi hak-hak reproduksi perempuan, pemerintah telah menerbitkan buku referensi pedoman PPAM kesehatan reproduksi pada situasi bencana. Buku ini bermanfaat bagi aktor kemanuasiaan dalam memberikan pelayanan terkait kesehatan reproduksi pada kondisi bencana. Namun salah satu kekurangan buku ini adalah tidak tersedianya kit menghadapi menstruasi pada situasi bencana. Hal ini terbukti dari penelitian Suryati (2013) yang menyatakan bahwa dari 12 kit yang ada di dalam PPAM kespro bencana, tidak satupun yang menyediakan tentang kebutuhan remaja pada menstruasi.

Kondisi menstruasi pada situasi bencana menuntut tersedianya kit menstruasi. Masalah yang sering ditemui adalah ketidaksiapan pihak kesehatan dalam persiapan alat, obat dan tenaga kesehatan yang siap siaga melayani. Pada saat bencana terjadi situasi kelihatan kacau. Walaupun rumah sakit dan puskesmas tetap buka, tetapi tenaga kesehatan banyak yang melarikan diri begitu juga dengan warung atau toko dan apotik yang tutup sehingga $80 \%$ kebutuhan remaha putri akan akses terhadap perlengkapan menstruasi tidak terpenuhi dengan baik (Suryati, 2013).

Berdasarkan hal tersebut remaja putri perlu dipersiapkan untuk dapat memberdayakan dirinya dalam menghadapi situasi bencana khususnya dalam bidang kesehatan reproduksi. Remaja putri harus tahu apa yang dibutuhkan dan harus dipersiapkan untuk menghadapi situasi bencana dan bagaimana cara mengatasi masalah umum terkait kesehatan reproduksi. Buku saku merupakan salah satu media untuk meningkatkan pengetahuan.

Berdasarkan survey pendahuluan yang dilakukan di SMAN 7 Kota Padang, dari 10 remaja putri, 8 orang diantaranya tidak mengetahui tentang persiapan yang harus dilakukan terkait dengan manajemen menstruasi pada situasi bencana dan 7 orang tidak mengetahui bagaimana cara mencegah kekerasan selama kondisi darurat bencana. SMAN 7 Kota Padang berada di Kecamatan Lubuk Buaya yang termasuk ke dalam salah satu zona merah terkena dampak tsunami. Berdasarkan wawancara dengan pihak sekolah, diketahui bahwa belum ada sosialisasi tentang manajemen mestruasi dan pencegahan pada situasi bencana termasuk penggunaan media buku saku.

\section{METODE PENELITIAN}

Penelitian ini menggunakan metode pre eksperimen dengan rancangan one group pre test dan post test design. Penelitian ini dilaksanakan pada bulan Mei sampai Oktober 2019 dengan tempat penelitian di SMAN 7 Lubuk Buaya Padang. Sampel diambil dengan teknik proportionate random sampling sebanyak 51 orang responden. Instrumen yang digunakan dalam penelitian ini berupa kuesioner yang berisi pernyataan yang terdiri dari pertanyaan pre test dan post test. Hasil uji normalitas data dengan Kolmogorov Smirnov menunjukkan data pre test dan post test berdistribusi normal.

Analisis univariat dilakukan untuk melihat rerata pengetahuan responden sebelum dan setelah penggunaan Buku Saku Higiene Menstruasi dan Pencegahan Kekerasan dalam Situasi Bencana. Analisis univariat dilakukan dengan 
menggunakan Dependent $T$ test dengan derajat kepercayaan $95 \%$.

\section{HASIL PENELITIAN}

Penelitian yang dilakukan terhadap 51 orang reponden yaitu siswi kelas XI
SMAN 7 Kota Padang. Responden berada pada rentang umur 15-16 tahun. Berikut adalah rata-rata pengetahuan remaja putri tentang Higiene Menstruasi dan Pencegahan Kekerasan dalam Situasi Bencana sebagai berikut:

Tabel 1. Rata-Rata Pengetahuan Remaja Putri tentang Higiene Menstruasi dan Pencegahan Kekerasan dalam Situasi Bencana Sebelum Intervensi

\begin{tabular}{lcccccc}
\hline \multicolumn{1}{c}{ Variabel } & N & Mean & Median & SD & Min & Maks \\
\hline Higiene menstruasi & 51 & 7,90 & 8,00 & 1,578 & 3 & 11 \\
Pencegahan kekerasan & 51 & 10,33 & 10,00 & 2,347 & 3 & 15 \\
\hline
\end{tabular}

Hasil penelitian pada tabel 1 7,90 dengan nilai SD 1,578, sedangkan
menunjukkan bahwa nilai rata-rata variabel pencegahan kekerasan dalam pengetahuan responden sebelum situasi bencana didapatkan nilai rata-rata intervensi pada variabel higiene 10,33 dengan nilai SD 2,347. menstruasi dalam situasi bencana adalah

Tabel 2. Rata-Rata Pengetahuan Remaja Putri tentang Higiene Menstruasi dan Pencegahan Kekerasan dalam Situasi Bencana Setelah Intervensi

\begin{tabular}{|c|c|c|c|c|c|c|}
\hline Variabel & $\mathbf{N}$ & Mean & Median & SD & Min & Maks \\
\hline Higiene menstruasi & 51 & 9,37 & 9,00 & 1,574 & 5 & 12 \\
\hline Pencegahan kekerasan & 51 & 11,65 & 12,00 & 1,764 & 7 & 15 \\
\hline
\end{tabular}

bahwa bahwa rata-rata pengetahuan sedangkan variabel pencegahan kekerasan responden setelah intervensi pada variabel dalam situasi bencana didapatkan nilai higiene menstruasi dalam situasi bencana rata-rata 11,65 dengan nilai SD 1,764.

Tabel 3. Pengaruh Penggunaan Buku Saku terhadap Pengetahuan Remaja Putri tentang Higiene Menstruasi dalam Situasi Bencana

\begin{tabular}{cccccc}
\hline Hygine Menstruasi & $\mathbf{N}$ & Mean \pm SD & Selisih(mean) & Median (Min-Maks) & $\boldsymbol{P}$-Value \\
\hline Sebelum Intervensi & 51 & $7,90 \pm 1,578$ & \multirow{2}{1}{47} & $8,00(3-11)$ & \\
Setelah Intervensi & 51 & $9,37 \pm 1,574$ & & $9,00(5-12)$ & $0,000 *$ \\
\hline
\end{tabular}

Tabel 3 menunjukkan bahwa berdasarkan uji $\mathrm{T}$ dependent diketahui nilai $\mathrm{p}<0,05$,menunjukkan ada perbedaan skor pengetahuan remaja putri tentang higiene menstruasi sebelum dan setelah pemberian intervensi.

Dengan demikian dapat disimpulkan bahwa terdapat pengaruh penggunaan buku saku terhadap pengetahuan remaja putri. Sebelum intervensi nilai mean sebesar 7,90. dan setelah intervensi nilai mean menjadi 9,37. Adanya peningkatan pengetahuan responden tentang hygine mestruasi dalam situasi bencana sebelum dan setelah dilakukan intervensi dengan menggunakan buku saku. Selisih peningkatan pengetahuan responden dari sebelum hingga setelah intervensi adalah 1,47 yaitu dengan persentase kenaikan sebesar $18,6 \%$. 
Tabel 4. Pengaruh Penggunaan Buku Saku terhadap Pengetahuan Remaja Putri tentang Pencegahan Kekerasan dalam Situasi Bencana

\begin{tabular}{lccccc}
\hline $\begin{array}{c}\text { Pencegahan } \\
\text { Kekerasan }\end{array}$ & N & Mean \pm SD & $\begin{array}{c}\text { Selisih } \\
\text { mean }\end{array}$ & $\begin{array}{c}\text { Median } \\
\text { (Min-Maks) }\end{array}$ & P-Value \\
\hline $\begin{array}{l}\text { Sebelum Intervensi } \\
\text { Setelah Intervensi }\end{array}$ & 51 & $10,33 \pm 2,347$ & 1,32 & $10(3-15)$ & $0,000^{*}$ \\
\hline
\end{tabular}

Tabel 4 menunjukkan bahwa berdasarkan uji $\mathrm{T}$ dependent diketahui nilai $\mathrm{p}<0,05$. Hal ini menunjukkan ada perbedaan skor pengetahuan remaja putri tentang pencegahan kekerasan sebelum dan setelah pemberian intervensi.

Dengan demikian dapat disimpulkan bahwa terdapat pengaruh penggunaan buku saku terhadap pengetahuan remaja putri tentang pencegahan kekerasan dalam situasi bencana. Rerata pengetahuan sebelum intervensi nilai mean sebesar 10,33 dan setelah intervensi nilai mean menjadi 11,65. Hal ini menunjukkan terjadi peningkatan pengetahuan responden tentang pencegahan kekerasan dalam situasi bencana sebelum dan setelah dilakukan intervensi dengan menggunakan buku saku. Terjadi peningkatan skor pengetahuan sebesar $1,32(12,7 \%)$.

\section{PEMBAHASAN}

Pada saat situasi darurat bencana, sebagian besar dari remaja putri mengalami menstruasi atau haid secara bergantian, umumnya mereka panik, dan juga malu karena tidak mempunyai pembalut wanita atau duk. Di antara mereka ada yang mengalami nyeri haid, ada yang mengalami pendarahan hebat,dan lain-lain. Oleh karena tidak terdapatnya persiapan pada saat pra bencana, sehingga harusnya mereka harus dibekali dengan pengetahuan tentang manajemen menstruasi pada situasi disaster. berkaitan dengan pencegahan kekerasan pada saat situasi darurat bencana. Untuk mencegah terjadiya kekerasan dalam kondisi bencana, perempuan harus dibekali dan diberikan pemahaman ciriciri serta apa langkah yang harus dilakukan ketika menghadapi bencana.

Sehingga perempuan dan masyarakat rentan lainnya dapat memberdayakan diri mereka dan mendapatkan bantuan jika terjadi kekerasan pada situasi bencana.

Penelitian yang dilakukan oleh Budhathoki et all, dengan judul Menstrual Hygine Menagement Amnong Women And Adolescent Girls In The Aftermath Of The Earthquake In Nepal Tahun 2018, hasil penelitian menemukan bahwa sebagian besar responden menyatakan bahwa manajemen higiene menstruasi merupakan hal yang sangat penting namun masih dianggap sebagai hal yang tabu. Pada penelitian yang sama pada tahap indept interview didapatkan bahwa informan tidak menyadari pentingnya menyediakan pembalut pada situasi bencana sampai mereka mengalami periode menstruasi pada saat bencana, karena ketidaktersediaan pembalut sehingga mereka tidak mau keluar dari tenda karena darah menstruasi telah mengotori pakaian mereka.

Ketidaktahuan remaja dalam mempersiapkan perlengkapan pada saat menstruasi pada situasi bencana menyebabkan mereka menggunakan pakaian bekas sebagai ganti pembalut, 
selain itu mereka juga tidak mengetahui pentingnya menyediakan sabun dan peralatan mandi lainnya untuk menghadapi situasi saat bencana (Budhathoki, et al, 2018).

Penelitian yang dilakukan oleh International Federation Of Red Cross And Red Cressent Societies menunjukkan bahwa pengetahuan sikap dan perilaku serta pemahaman tentang hak-hak yang berkaitan dengan kekerasan pada perempuan sangat rendah pada populasi terdampak bencana dan pada penelitian yang sama ini juga melalui indept interview terhadap informan menunjukkan bahwa wanita tidak memahami tentang bagaimana mencegah kekerasan pada situasi (International Federation Of Red Cross And Red Cressent Societies, 2015).

Pentingnya melakukan manajemen menstruasi dan pencegahan kekerasan bagi remaja putri pada saat terjadinya bencana seperti mempersiapkan remaja putri dengan pengetahuan tentang peralatan yang dibutuhkan pada saat menstruasi seperti pembalut, peralatan mandi sehingga remaja putri dapat melalui periode mentruasi tanpa masalah dapat menghindari kekerasan yang dapat mengancam diri mereka ketika terjadi bencana.

Penggunaan buku saku adalah salah satu media yang tepat untuk meningkatkan pengetahuan. Media pada hakikatnya adalah alat bantu dalam menyampaikan informasi. Penggunaaan buku saku yang menarik dapat merangsang rasa ingin tahu individu terhadap suatu objek, oleh karena itu perlu disiapkan sedemikian rupa agar lebih menarik dan merangsang indera penglihatan manusia untuk memperhatikan isi dari informasi yang disampaikan (Notoatmodjo, 2003).
Masih ditemukannya responden yang masih sebagian besar menjawab salah tentang beberapa peralatan dan pembalut yang dapat dipakai ulang hal ini kemungkinan disebabkan oleh masih asingnya bagi mereka tentang manajemen menstruasi dalam situasi bencana dan masih tabu bagi mereka membicarakan tentang kesehatan reproduksi pada situasi bencana. Hal lain juga berkaitan degan pencegahan kekerasan hal ini mungkin disebabkan oleh responden belum pernah merasakan dampak bencana secara langsung sehingga belum dapat membayangkan upaya apa yang harus dilakukan serta akibat apa yang dapat terjadi jika terjadi kekerasan dalam situasi bencana.

Melalui buku saku yang dikembangkan ini dapat menjawab dan memenuhi kebutuhan remaja putri dalam menambah pengetahuan mereka dan dapat melakukan persiapan peralatan yang dibutuhkan saat menstruasi dalam situasi bencana. Pada penelitian ini pemberian edukasi dengan media buku saku sudah mampu memberikan informasi yang sesuai dengan karakteristik remaja putri dan edukasi mitigasi bencana kesehatan reproduksi merupakan langkah yang strategis dalam upaya peningkatan kesehatan reproduksi remaja putri khususnya hygine menstruasi dan pencegahan kekerasan dalam situasi bencana.

Pendidikan kesehatan merupakan salah satu proses untuk meningkatan pengetahuan seseorang, pengetahuan dapat meningkat karena informasi dari orang lain, media massa elektronik seperti radio, televisi, leaflet, majalah (Notoatmodjo, 2003). Berdasarkan hasil penelitian yang diperoleh terdapat proses yang sejalan antara peningkatan 
pengetahuan dan hal ini menunjukkan bahwa antara hasil penelitian sejalan dengan teori.

Pemberian edukasi buku saku yang diberikan telah didesain semenarik mungkin dengan materi yang tidak terlalu banyak dan disertai dengan gambargambar yang menarik sehingga responden dapat membaca sekalian melihat contoh dari gambar tersebut. Buku saku yang diberikan berisi tentang pengertian mentruasi, mitos-mitos yang beredar dimasyarkat berkaitan dengan menstruasi, hal-hal yang harus disiapkan dan dilakukan selama mentruasi dalam situasi bencana yang di dukung oleh gambar dengan ukuran buku 11 x $8 \mathrm{~cm}$. Buku saku merupakan buku dengan ukuran kecil yang dapat dimasukkan ke dalam saku dan mudah dibawa kemana-mana (Poerwadarminta, 2006). Dengan keefektifan buku saku tersebut siswa dapat memperoleh informasi pengetahuan hygine selama menstruasi dalam kondisi bencana.

Media edukasi yang baik adalah media yang mampu memberikan informasi atau pesan pesan kesehatan yang sesuai dengan tingkat penerimaan sasaran, sehingga sasaran mau dan mampu untuk merubah pengetahuan sesuai dengan pesan-pesan yang disampaikan. Pemberian edukasi dengan media edukasi buku saku sudah mampu memberikan informasi yang sesuai dengan karakteristik remaja putri dan disekolah merupakan langkah yang strategis dalam upaya peningkatan kesehatan masyarakat khususnya dalam mengembangkan prilaku hidup sehat .

Selain higiene menstruasi, buku saku inijuga berisi materi tentang pencegahan kekerasan dalam situasi bencana. Setidaknya sepertiga dari populasi perempuan di dunia pernah mengalami kekerasan fisik atau seksual pada satu waktu dalam hidupnya. Walaupun hanya sedikit penelitian yang dilakukan oleh banyak negara mengenai masalah ini, data yang tersedia menunjukkan bahwa di beberapa negara hampir satu dari empat perempuan menderita kekerasan seksual yang dilakukan oleh pasangan, dan sepertiga remaja perempuan melaporkan pengalaman seksual pertama mereka dilakukan dalam keadaan terpaksa. Dalam konteks konflik bersenjata dan pengungsian, kekerasan seksual, termasuk eksploitasi dan penganiayaan, sering terjadi dan merupakan masalah berisiko tinggi. Kekerasan seksual sering digunakan sebagai alat perang, dengan perempuan dan anak-anak sebagai sasaran (UNFPA, 2016).

Anak-anak dalam keadaan darurat bisa berada di bawah risiko kekerasan seksual karena tingkat ketergantungan mereka yang tinggi, dimana kemampuan untuk melindungi diri sendiri terbatas sementara tidak dalam posisi untuk mengambil keputusan untuk dirinya sendiri. Karena mereka memiliki sedikit pengalaman hidup, anak-anak juga lebih mudah dieksploitasi, ditipu dan dipaksa dibandingkan dengan orang dewasa. Tergantung dari tingkat perkembangan mereka, anak-anak tidak mengerti secara keseluruhan sifat dasar seksual dari tindakan tertentu, dan mereka tidak mampu memberikan persetujuan sendiri. Perempuan remaja dan wanita muda bisa menjadi target kekerasan seksual selama konflik bersenjata atau kondisi bencana (UNFPA, 2016).

Membekali remaja putri dalam meningkatkan pengetahuan mereka tentang pencegaan kekerasan pada situasi 
bencana juga dapat dilakukan dengan menggunakan media salah satunya adalah dengan menggunakan buku saku, karena buku saku dipandang sebagai media yang efektif untuk meningkatkan pengetahuan. Hal ini sesuai dengan hasil penelitian Eliana dan Solikhah dimana media buku saku sangat berperan penting dalam peningkatan pengetahuan gizi. Fungsi media dalam pendidikan adalah sebagai alat peraga untuk menyampaikan informasi atau pesan pesan tentang kesehatan (Eliana \& Solikhah, 2012).

\section{KESIMPULAN DAN SARAN}

Terdapat pengaruh penggunaan buku saku terhadap pengetahuan remaja putri tentang higiene menstruasi dalam situasi bencana, dengan nilai $\mathrm{p}<0,05$. Rata-rata pengetahuan remaja putri tentang higiene menstruasi dalam situasi bencana sebelum intervensi adalah 7,90 dan pencegahan kekerasan dalam situasi bencana sebelum intervensi adalah 10,33. Rata-rata pengetahuan remaja putri tentang higiene menstruasi setelah intervensi adalah 9,37 dan pencegahan kekerasan dalam situasi bencana setelah intervensi adalah 11,65. Diharapkan buku saku ini dapat dimanfaatkan sekolah sebagai media pendidikan bagi remaja putri dalam meningkatkan kesiapsiagaan bencana khususnya terkait kesehatan reproduksi.

\section{DAFTAR RUJUKAN}

Bhattacharjee, M. (2019). Menstrual hygiene management during emergencies: a study chalenges faced by women and adolescent girls living in flood[prone district in Assam. Indian Journal Fof Gender Studies.

BNPB. (2017). Laporan Tahunan 2017
Pusdalops-PB Sumatera Barat. Padang.

Budhathoki, S. S., Bhattachan, M., CastroSánchez, E., Sagtani, R. A., Rayamajhi, R. B., Rai, P., \& Sharma, G. (2018). Menstrual hygiene management among women and adolescent girls in the aftermath of the earthquake in Nepal. BMC Women's Health, 18(1). Retrieved from https://doi.org/10.1186/s12905018-0527-y

International Federation.of Red Cross and Red Cressent Societies. (2015). Unseen, unheard: Gender-based violence in disasters Global study. Geneva.

Kementerian Kesehatan RI. (2017). Pedoman pelaksanaan paket pelayanan awal Minimum (PPAM) kesehatan reproduksi pada krisis kesehatan. Jakarta: Kementerian Kesehatan RI.

Maknun, S. S., Nahar, N., Kabir, H. (2017). Women health and menstrual hygiene management in natural disasters: a study in islampur upazila of jamalpur district. J. Asiat.Soc. Bangladesh.Sci, 43(1), 83-99.

Masson, V. L., Lim, S., Budimir, M., Podboj, J. S. (2016). Disaster and violence againts women and girls. London.

Notoatmodjo, S. (2003). Pendidikan dan Perilaku Kesehatan. Jakarta: Rineka Cipta. 
Poerwadarminta. (2006). Kamus Umum

Bahasa Indonesia. Jakarta: Balai Pustaka.

Sneha Krishnan, J. T. (2016). Menstrual hygiene: A "silent" need during disaster recovery. Waterlines, 35(3), 265-276.

Solikhah, E. (2012). Pengaruh Buku Saku Gizi terhadap Tingkat Pengetahuan Gizi pada Anak Kelas 5 Muhammadiyah Dadapan Desa Wonokerto Kecamatan Turi Kabupaten Sleman Yogyakarta. Kemas: Jurnal Fakultas Kesehatan Masyarakat, 6(2).

Sommer, M., Schmitt, M., \& Clatworthy, D. (2017). A toolkit for integrating (MHM), Menstrual Hygiene Management Edit)., into humanitarian response. New York.

SPLASH. (2015). Menstrual Hygiene Management. Washington D.C.

Suryati. (2013). Gambaran Kebutuhan dan Perilaku Remaja Putri. Jurnal Kesehatan Masyarakat 7(2), 60-65.

UNFPA. (2016). Adolescent Girls in Disaster \& Conflict: New York. 